\title{
Helminth Parasites of the Green Toad Bufo viridis Laurenti, 1768 in Baghdad Area, Central Iraq
}

\author{
Mohammad K. Mohammad, Azhar A. Al-Moussawi , Suhad Y. Jasim \\ Iraq Natural History Research Centre and Museum. Baghdad University, Baghdad, \\ Iraq. \\ E-mail contact: ahmeda_09@yahoo.com
}

\begin{abstract}
Examination of a small collection of the green toad from Baghdad area, central Iraq revealed presence of two cestodes Proteocephalus sp. and Nematotaenia dispar and four nematodes Oswaldocruzia filiformis, Cosmocerca commutat, Cosmocercoides variabilis and Rhabdias bufonis.
\end{abstract}

Keywords. Bufo viridis ,Proteocephalus sp., Nematotaenia dispar, Oswaldocruzia filiformis, Cosmocerca commutata, Cosmocercoides variabilis, Rhabdias bufonis.

\section{INTRODUCTION}

The green toad Bufo viridis Laurenti, 1768 is recorded in 52 countries according to IUCN-GAA, Biodiversity Assessment Unit, Center for applied Science), it appeared in the red list of as LC (Least Cocern) (IUCN, 2006) and distributed in much of Europe, Russia, Mongolia, Mediterranean countries, and southwest Asia in Iran, Iraq, Jordan, Lebanon, Palestine, Saudi Arabia, Syria, and Turkey (Stock et al., 2001). In Iraq, it is one of the most common amphibians among eight species that constitute the Iraqi amphibian fauna (Mahdi and George, 1969). It is widely distributed in the north and middle ( Khalaf, 1959) inhabiting open areas often somewhat faraway from water bodies, especially in the wetlands, orchards, gardens, cases and shores of irrigation ditches and lakes.

Although little is known about the amphibian parasites in the Middle East (AlSorkhy and Amr, 2003) ; some studies on the subject are available in the adjacent countries including Mashaii (1999, 2005) and Mashaii et al.(2000) from Iran, Madi (1976) and Al-Sorkhy and Amr (2003) from Jordan, Oguz et al.( 1994), Yildirimhan (1999a,b ), Yildirimhan et al. (1996, 1997a,b, , 2001a,b, 2005a,b, 2006a,b), Dusen and Oz (2004), Dusen (2007) and Yildirimhan and Karadeniz (2007) from Turkey. In Iraq, rather few works were carried out on the subject. Saeed et al. (2007) gave an excellent revision of the works on parasites of Iraqi amphibians. The papers that deal with Rana esculenta are (Sauod and Roshdy 1969, 1970); with Rana ridibunda are (Dauood, 1974; Al-Barwari and Nassir, 1983; Hamad, 1985; Molan et al., 1989; with Hyla arborea are (Dauood, 1974; Al-Barwari and Nassir, 1983) and finally with Bufo viridis (Dauood, 1974; Hamad, 1985; Al-Alousi, 1994; Rahemo and Ami, 1995).

The present work aims to investigate about the helminth parasites of the green toad in Baghdad area.

\section{MATERIALS AND METHODS}

A total of 25 adult specimens of the green toad Bufo viridis were collected at Bab Al-Muadham, Baghdad City, Central Iraq during the period May 2006 to March 2008. 
The toads were immediately transferred to the laboratory, sacrificed and dissected as soon as possible. All viscera were removed and each placed in petri dish with normal physiological saline. The viscera were examined for helminths under a dissecting microscope. The lungs were cut and checked out for infection. The recovered helminthes were cleaned carefully. Cestodes were fixed in $70 \%$ alcohol while being slightly pressed between two glass slides, stained with acetocarmine, dehydrated in a series of alcohol concentrations of $80 \%, 90 \%$ and $100 \%$, cleared in xylene and mounted in Canada balsam. The nematodes were fixed in $70 \%$ alcohol and cleared in lactophenol.

\section{RESULTS AND DISCUSSION}

Table 1 summarizes the results of recovering helminth parasites from the green toad specimens collected in Baghdad area. This would show that 12 (including 7 males and 5 females) out of 25 specimens (48\%) were found infected with one or more species of either cestodes or nematodes or both.

Although cestodes appeared only in three females along with nematodes in two cases, the small size of the sample host specimens could not allow us to withdraw any conclusion in regard to the effect of host sex on the infection..

It is obvious that overall infection with nematodes is far exceeds that with cestodes since all of the infected specimens contains one or more species of the recorded nematodes in this study. Infection rate with nematodes is $44 \%$ while that of cestodes $12 \%$. This is in agreement with Saeed et al. (2007) who examined 73 host specimens in northern Iraq.

Proteocephalus sp.: it is a larval stage cestode appeared once in a specimen acquired a triple infection of this cestode, the cestode Nematotaenia dispar and the nematode Cosmocerca commutata. This species was reported from B. viridis and Hyla arborea in Turkey (Yildirimhan, 1999b ; Dusen and Oz, 2004). Other records include Moravec and Kaiser (1995) from the reptile Eleuthendactylus sp. in the Indies, South America, and Muzall et al. (2001) from Rana clamitans from U.S.A.

Table1: Helminth parasite group and species, infection sites, infection rate, intensity, range and sex ratio.

\begin{tabular}{|c|c|c|c|c|}
\hline Helminth species & Infection site & $\begin{array}{l}\text { No. hosts } \\
\text { infected }\end{array}$ & $\%$ infection & $\begin{array}{c}\text { No. parasites/host(range) } \\
\text { (male: female) }\end{array}$ \\
\hline \multicolumn{5}{|l|}{ Cestodes } \\
\hline Proteocephalus sp. & Small intestine & 1 & 4 & 2 \\
\hline Nematotaenia dispar & Small intestine & 3 & 12 & $1.3(1-3)$ \\
\hline \multicolumn{5}{|l|}{ Nematoda } \\
\hline Oswaldocruzia filiformis & intestine & 3 & 12 & $5(1-8)(3: 12)$ \\
\hline Cosmocerca commutata & intestine & 5 & 28 & $4(3-12)(3: 11)$ \\
\hline Cosmocercoides variabilis & rectum & 4 & 20 & $3.3(1-8)(3: 8)$ \\
\hline Rhabdias bufonis & lung & 1 & 4 & $2(0: 2)$ \\
\hline
\end{tabular}

Nematotaenia dispar (Goeze, 1782) : In his revision of the Cyclophyllidean family Nematotaeniidae, Jones (1987) mentioned that this cestode is a variable species which covers a broad geographical range extending throughout North Africa, the Middle East, Europe, India South East Asia and U. S. A. It is widely distributed among amphibian and reptilian hosts. Although it is primarily a parasite of bufonidae (e.g. Bufo alvarius, B. americanus, B. bufo, B. cinereus, B. congatus , B. lentigenosus, B. melosticus, B. punctatus , B. regularis, B. terrestris, B. viridis, B. vulgaris) (Douglas, 1958; Al-Barwari and Nassir, 1983; Jones, 1978; Mashaii, 1999; Goldberg et al . 1996 ; Yildirimhan, 1996 ; Vashetko and Siddikov, 1999; Al-Sorkhy 
and Amr, 2003), it was also reported from Acris gryllis and Hyla arborea (Hylidae), Rana agilis, $R$. camerani, $R$. dalmatina, $R$. halecina, $R$. pipiens, $R$. temporaria and $R$. virescens (Ranidae), Pleobates fuscus (Pleobatidae), Mertensiella caucasica , Salamandra salamandra and Triturus alpestris (Salamandriidae), Menobranchus maculates (Proteidae) and from the lizards Varanus griseus (Varanidae) and Platydactylus guttatus (Gekkonidae) (Jewell, 1916; Douglas, 1958; Dollfus, 1965; AlBarwari and Nassir, 1983; Jones, 1987; Mashaii, 1999; Yildirimhan et al., 2005a , 2006b)

In regard to its presence in the green toad, it seems that its distribution coincides with the geographical distribution of the green toad since it was recorded in France, Iran, Iraq, Kuwait ,Tunisia, Turkey and U.S.A. Saeed et al. (2007) found it in 56\% of examined specimens while infection rate with parasite in present study is $12 \%$. This may reflects wide ecologic and consequently biological differences between the two collection sites, the northern and central Iraq. Jones (1987) examined only one specimen from Iraq mentioning that the number of the paruterine capsules is 30-33 and the eggs per capsule are 2-5. The paruterine capsules of our cestode specimens are around 20. In view of the present results in regard to number of paruterine capsules and the number of eggs per capsule, it seems that we have in Iraq more than one infraspecific rank of the cestode species although all of specimens of Jones (1987) and the present work were from $B$. viridis.

Oswaldocruzia filiformis (Goeze, 1782) (Fig. 1 A \& B) : the infection rate in this study is $14.3 \%$. This seems low when compared with that reported by Saeed et al. (2007). This is may related to smaller host sample size of this study (25) compared with (73) of their study. This nematode is a cosmopolitan parasite of amphibians and reptiles (Saeed et al., 2007). It was first recorded in Iraq by Al-Barwari and Nassir (1983) from B. viridis.

Also, it has been reported from the same host (Walton, 1935 in Europe; Yildirimhan, 1999b in Turkey), from Bombina bombina ; B. varigata (Walton, 1935 in Europe ; Kirin and Buchvarov, 2002) Bufo americanus , B.bufo ; B.crucifer; B. hemiphrys ; B. viridis ; B.valliceps (Walton, 1935 in Europe ; Bursey and Goldberg, 1998 in Canada; Yildrimihan and Karadeniz, 2007 in Turkey) Rana arvalis isaitschikovi (Walton, 1938 in Europe) R. camerani (Y1ldırımhan et al., 2006b in Turkey) R. dalmatina (Kirin, 2003 in Europe) R. macrocnemis; R. esculenta; (Walton, 1935, 1938 in Europe ) $R$. ridibunda ; $R$. temporaria (Walton ,1935; 1938; Kirin and Buchvarov , 2002 in Europe) Hyla arborea; Pleobatus fuscus; Salamandra atra ; S. salamndra ; Triturus cristatus ; T. vulgaris (Walton, 1935 in Europe) Ceratophrys dorsata and Leptodactylus ocellatus (Walton, 1935 in Brasil).

Cosmocerca commutata (Diesing, 1851) (Fig. 2): Its infection rate in this study is $23.8 \%$. This seems very high compared with that given by Saeed et al. (2007) from Rana ridibunda in the north of Iraq. Both smaller sample size of this study along with different host and locality may play role in this difference. It was reported from $B$. viridis (Mashaii, 1999 in Iran; Yildirimhan, 1999b in Turkey), from Hyla arborea (Dusen and Oz, 2004 in Turkey) and from Rana ridibunda (Vashetko and Siddikov, 1999 in Uzbekistan; Kirin, 2003 in Bulgaria; Saeed et al., 2007 in Iraq). It was also reported from Bufo marinus ; Leptodactylus typlaonius in Brazil and from Bombina bombina; Bufo bufo; B. viridis; Hyla arborea; Pelobates fuscus; Rana esculenta; $R$. temporaria; Salamandra atra; S. salanzandra and Triturus cristatus in Europe (Walton, 1933 ).

Cosmocercoides variabilis (Harwood, 1930) (Fig. 3 A.; B \& C): it was reported from different amphibian families i.e.: Ambystomatidae; Bufonidae; Plethodontidae, 
Ranidae and Salamandridae (Joy and Bunten, 1997; Bursey and DeWolf, 1998; Bolek and Coggins, 2003; McAllister and Bursey, 2004). It was reported in U.S.A. from Acris grylus ; Ambystoma microstomum; A. opacum; Ambystoma talpoideu, Bufo americanus americanus, Bufo borea, B. hemiophrys, B. quercicus, B. terrestris,B. valliceps Eurycealongicauda E. lucifuga Gastrophryne aredata , G. carolinensis, Hyla cinerea, $H$. squirella, Pseudacris trieriata. Rana aesopus, $R$. areolata, $R$. aurora, $R$. catesbeiana, $R$. clamitans, $R$. palustris, $R$.sphnocephala, $R$. sylvatica, Triturus meridionalis and Triturus torosus (Walton, 1933; 1938; Bursey and DeWolf 1998; Bolek and Coggins, 2003 McAllister and Bursey,2004).

Rhabdias bufonis (Schrank, 1788) : Our results showed females of Bufo viridis got more numbers of this worm than that of their counter in males, in contrast with Saeed et al.(2007) who found that males of B. viridis collected from many localities of northern Iraq acquired more $R$. bufonis than females

Adults were recovered from the lungs. It is a worldwide parasite of toads and frogs (Saeed et al., 2007). Fifteen species of Rhabdias have been reported from members of Bufonidae but this species seems not specific to the host family Bufonidae since it infects members of Ranidae (Kirin, 2003; Yildirimhan, 2006 a; b). It was reported from B. viridis (Walton ,1933 ; in Europe; Yildirimhan,1999b in Turkey ; Mashaii , 2005 in Iran and Saeed et al., 2007) Bombina bombina; B. bufo (Walton,1933 in Europe; Yildirimahan and Karadenis, 2007 in Turkey) ; B. americanus (Walton,1933 in U.S.A) Hyla arborea japonica; Pelobates fuscus (Walton, 1933 in Japan) Rana arualis isaitschikovi (Walton,1938 ; in Europe), Rana camerani (Yildirimhan et al., 2006 b in Turkey ) R. esculenta ; R. japonica (Walton, 1933, 1949 in Europe and Japan) R. macrocnemis (Walton , 1933 in Europe ; Yildirimhan et al., 2006 a in Turkey) $R$. nigromaculata, and $R$. rugosa (Walton, 1933 in Japan) $R$. ridibunda (Walton, 1933 in Turkestan; Kirin, 2003 in Europe) and R. temporaria (Walton, 1933 in Europe).

\section{ACKNOWLEDGEMENTS}

We are grateful to Dr. Boyko Georgiev, Researcher, Natural History Museum, London, Dr. Stephen R. Goldberg, The Pennsylvania State University, U.S.A. and Dr. Nassrin Mashaii, Brackish water Fisheries Research Station, Iran, for confirming specific identity of some helminths of this study

\section{REFERENCES}

Al-Alousi, T. I. (1994): Biological and morphological studies on spargana isolated from toads Bufo viridis . Iraq Veterinary Science. 7:207-212, Iraq.

Al-Barwari, S. E. and Nassir,J. K. (1983) : First record of ten species on spargana isolated from toads Bufo viridis. Iraqi J. Vet. Science, 7: 207-212, Iraq.

Al-Sorkhy, M. K. and Amr, Z.(2003): Platyhelminth parasites of some amphibians in Jordan. Turk. J. Zool., 27: 89-93, Jordan.

Bolek, M. G. and Coggins, J. R. (2003): Helminth community structure of sympatric eastern American toad, Bufo americanus americanus, northern leopard frog, Rana pipiens, and blue-spotted salamander, Ambystoma laterale, from southeastern Wisconson. J. of Parasitol. 89(4): 673-680, U.S.A.

Bursey, C. R. and DeWolf, W. F., II (1998): Brief note: Helminths of the frogs, Rana catesbeiana, Rana clamitans, and Rana palustris, from Coshocton County, Ohio. The Ohio Journal of Science, 98(2): 28-29,U.S.A. 
Bursey, C. R. and Goldberg, S.R. (1998): Helminths of the Canadian Toad, Bufo hemiophrys (Amphibia:Anura), from Alberta , Canada . J.of Parasitol. 84(3):617-618, Canada.

Dauood, K. S. (1974): Studies on the protozoan and trematode parasites of some amphibians from Nienava District, North Iraq. M.Sc. thesis, Mosul University, Mosul, Iraq.

Dollfus, R. P. (1965): Mission Yves.-J.Golvan et Jean-A. Rioux en Iran. Cestodes de carnivores,rongeurs, insectivores, reptiles et batraciens. Annales de Parasitologie Humaine et Comparee, 40: 61-86.

Douglas, L. T. (1958): The taxonomy of nematotaeniid cestodes. J. Parasitol., 44(3): 261-273.

Dusen, S. (2007): Helminths of the two mountain frogs , Banded Frog, Rana Camerani Boulenger, 1886 and Uludag Frog Rana macrocnemis Boulenger, 1885 (Anura: Ranidae ), collected from the Antalya Province . Turkiye Parazitoloji Dergisi .31(1):84-88,Turkey.

Dusen, S. and Oz, M. (2004): Helminth parasites of the tree frog, Hyla arborea (Anura: Hylidae) from southwest Turkey. Comparative Parasitology, 71(2): 258-261, Turkey.

Goldberg, S.R. ; Bursey, C.R.; Gergus , W.A. ; Sullivan , B.K. and Truong, Q.A. (1996 ): Helminths from three treefrogs Hyla arnicolor ,H. wringtorum and Pseudacris triseriata (Hyalidae) from Arizona. The Journal of Parasitology 82(5): 833-835,U.S.A.

Hamad, N. R. (1985): A taxonomic study of digenetic trematodes of some Iraqi vertebrates. M. Sc. Thesis, Salahuddin University, Erbil, Iraq.

IUCN (2006): Global Amphibian Assessment website. Biodiversity Assessment Unit, Center for Applied Science

Jewel M. E. (1916): Cylindrotaenia americana Nov. Spec. from the Cricket Frog. The Journal of Parasitology, 2(4): 181-192.

Jones, M. K. (1987): A taxonomic revision of the Nematotaenidae Luhe, 1910 (Cestoda: Cyclophyllidea). Systematic Parasitology, 10: 165-245.

Joy, E. J. and Bunten, C. A. (1997): Cosmocercoides variabilis (Nematoda, cosmocercoidea) populations in the eastern American toad Bufo americanus (Salientia: Bufonidae) from western Virginia. J. Helminth. Soc. Wash., 64: 102-105 U.S.A.

Khalaf, K.T. (1959): Reptiles of Iraq with some notes on the amphibians.Ar-Rabitta Press,Baghdad , PP.96 ,Iraq.

Kirin, D. A. (2003): Biodiversity and ecological particulars of the helminth communities in Rana ridibunda Pallas, 1771 from the districts of town Saedinenie, Bulgaria. Experimental Pathology and Parasitology, 6 (11): 31-36, Bulgaria.

Kirin, D. and Buchvarov, G. (2002): Biodiversity of the helminthes communities of acaudated amphibians (Amphibia-Ecaudata) from Bistritsa riverside (Gotse Delchev region). Experimental Pathology and Parasitology, 5 (8): 13-16.

Madi , M. (1976): Systematic and morphological studies on genetic trematodes from some aquatic vertebrates of the Azraq area . MS.C. Thesis, The Jordan University,Jordan.

Mahdi N. and George, P.V. (1969): A systematic list of the vertebrates of Iraq. Iraq Natural History Museum, Publication No. 26, PP.104, Iraq. 
Masshaii, N., (1999): New Records of Trematode Parasites (Digenea) in the Banded Frog (Rana camerani) and Marsh Frog (Rana ridibunda ridibunda) (Anura: Ranidae), from Southwest of Iran. Iranian Journal of Fisheries Sciences, 1: 41-47, Iran.

Mashaii, N., Balouch, M., Mobedi, I.( 2000): New Records about Helminth Parasites of the Marsh Frog, Rana ridibunda ridibunda (Anura: Ranidae), from the North of Iran. Iranian Journal of Fisheries Sciences, 2 (2): 77-88, Iran.

Mashaii, N., (2005): Helminth Parasites of green toad, Bufo viridis (Anura: Bufonidae), Tree frog, Hyla arborea savignyi (Anura: Hylidae) and Marsh Frog, Rana ridibunda ridibunda (Anura: Ranidae) from Southwest of Iran. Iranian Journal of Veterinary Research, 6 (3): 67-73, Iran.

McAllister, C. T and Bursey, C. R. (2004): Endoparasites of the dark-sided salamander, Eurycea longicauda melanopleura, and the cave salamander, Eurtcea lucifuga (Caudata: Plethodontidae), from two caves in Arkansas, U. S. A. Comparative Parasitology, 71(1): 61-66.U.S.A.

Molan, A. L.; Saeed, I. S. and Miyata, A. (1989): Haematoprotozoa in Rana ridibunda in Iraq. Proc. Jap. Soc. Sys. Zool., 40: 3-12, Iraq.

Moravec, F. and Kaiser, H. (1995): Helminth parasites from West Indian frogs, with description of two new species. Caribbean Journal of Science, 31 (2-3): 252-268, India.

Oğuz, M. C.; Altunel, F.N. and Uğurtaş, İ.H., (1994): Edirne ve Bursa İlleri Çevresinde Yakalanan Ova Kurbağası (Rana ridibunda Pallas, 1771)'nın Parazitleri olan Plathelminth'leri ile Acanthocephalus ranae (Schrank, 1788), (Echinorchynchidae, Acanthocephala) Üzerinde Araştırmalar. Turkish Journal of Zoology, 18: 47-51, Turkey.

Rahemo, Z. I. F. and Ami, S. N. (1995): Microtetramers sp. Larvae (Nematoda: Tropisuridae) encysted in the stomach wall of toad, Bufo viridis in Iraq. Revue Roumaine De Biologie-Biologie Animale, 40: 19-23.Iraq.

Saeed, I.; Al-Barwari, S. E. and Al-Harmni, K. I. (2007): A metazoan parasitological research of some Iraq amphibians. Turkiye Parazitoloji Dergisi, 31 (4): 337-345, Iraq.

Saoud, M. F. A. and Roshdy, M. A. (1969): Opisthioglyphe endoloba (Dujardin, 1845); a parasite of the frog, Rana esculenta in Iraq. Curr Sci., 38: 515516, Iraq.

Saoud, M. F. A. and Roshdy, M. A. (1970): On Halipegus alhaussaini n. sp. (Trematoda: Halipegidae) from Rana esculenta in Iraq, with notes on Halipegus and related genera. J. Helminth., 44: 349-356,Iraq.

Stock, M.; Frynta, D.; Grosse, W.-R.; Steinlein, C. and Scmid, M. (2001): A review of the distribution of the diploid, triploid and tetraploid green toads (Bufo viridis complex) in Asia including new data from Iran and Pakistan. Asiatic Herpetological Research, 9: 77-100

Vashetko, E. V. and Siddikov, B. H. (1999): The effect of the ecology of toads on the distribution of helminthes. Tr. J. Zool., 23: 107-110.

Walton, A.C. (1933): The nematoda as parasites of amphibia. J. Parasitol., 20(1): 132, U.S.A.

Walton, A.C. (1935): The nematode as parasites of amphibian. II. J. Parasitol., 21(1): 27-50.U.S.A.

Walton, A. C. (1938): The nematoda as parasites of amphibia. IV. Transactions of the American Microscopical Society, 57(1): 38-53.U.S.A. 
Yildirımhan, H. S.; Uğurtaş, İ. H. and Altunel, F. N. (1996): Rana ridibunda Pallas, 1771(Ova Kurbagası)'nın Helmintleri Üzerinde Bir Araştırma. Türkiye Parazitoloji Dergisi (Acta Parasitologica Turcica), 20: 113-130, Turkey.

Yildirımhan, H. S.; Oğuz, M. C. and Uğurtaş, İ. H., (1997a): Bursa ve Çevresinden Yakalanan Bazı Kuyruksuz Kurbagaların (Rana ridibunda, Bufo bufo, Pelobates syriacus) Nematodları Üzerine Bir Araştırma. Hacettepe Fen ve Mühendislik Bilimleri Dergisi, 18: 45-58, Turkey.

Yildirımhan, H. S.; Uğurtaş, İ. H. and Altunel, F. N. (1997b): An investigation on parasitic helminths of Rana macrocnemis Boulenger, 1885 (Uludag frog). Turkish Journal of Zoology 21: 467-473 Turkey.

Yildirımhan, H. S. (1999a): Bursa ve Çevresinde yayılış Gösteren Lacertidae (Reptilia) Familyasına ait Kertenkele Türlerinin Helmint Faunası. Doktora Tezi, Uludağ Üniversitesi Fen Bilimleri Enstitüsü. 120 ss, Bursa, Turkey.

Yildirımhan, H. S. (1999b): Researches on parasitic helminths of Bufo viridis Laurenti, 1768 (Anura: Amphibia). Turkish Journal of Zoology, 23:177195 Turkey.

Yildirımhan, H. S.; Aydoğdu, A.; Uğurtaş, İ. H. and Altunel, F. N. (2001a): Sakarya ve Edirne'denYakalanan Bombina bombina (Linnaeus, 1761) (Kırmızilı Kurbağa)'nın Helmint Faunasi. Türkiye Parazitoloji Dergisi (Acta Parasitologica Turcica), 25:308- 311 Turkey.

Yildirımhan, H. S.; Aydoğdu, A.; Uğurtaş, İ.H. and Altunel, F.N. (2001b): Kuyruklu Kurbağalardan Mertensiella caucasica (Kafkas Semenderi)'nin Plathelminthleri ve Acanthocephalleri Üzerine Bir Ön Araştırma. Türkiye Parazitoloji Dergisi (Acta Parasitologica Turcica), 25: 393-397, Turkey.

Yildirımhan, H. S.; Bursey, C. R. and Goldberg, S.R. (2005a): Helminth Parasites of the Caucasian Salamander, Mertensiella caucasica, from Turkey. Comparative Parasitology, 72 (1): 75-87, Turkey.

Yildirımhan, H. S.; Karadeniz, E.; Gürkan, E. and Koyun, M. (2005b): Türkiye'nin Değişik Bölgelerinden toplanan Ova Kurbağası (Rana ridibunda PALLAS, 1771; Anura)'nın Metazoon Parazitleri. Türkiye Parazitoloji Dergisi (Acta Parasitologica Turcica) 29 (2): 135-139, Turkey.

Yildirımhan, H. S.; Bursey, C.R. and Goldberg, S.R. (2006a): Helminth parasites of the Taurus frog, Rana holtzi, and the Uludag frog, Rana macrocnemis, with remarks on the helminth community of Turkish anurans. Comparative Parasitology. 73 (2): 237-248, Turkey.

Yildirımhan, H. S.; Goldberg, S. R. and Bursey, C.R. (2006b): Helminth Parasites of the Banded Frog Rana camerani (Ranidae) from Turkey. Comparative Parasitology, 73 (2): 222-236, Turkey.

Yildirimhan, H. S. and Karadeniz, E. (2007): Helminth parasites of the common toad, Bufo bufo (Linnaeus, 1758) (Anura: Bufonidae) from Northeast Turkey. Comparative Parasitology, 74 (1): 176-178, Turkey. 


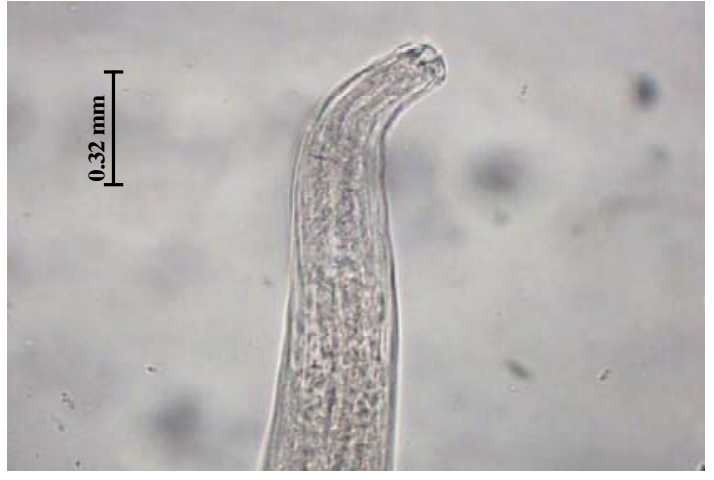

A

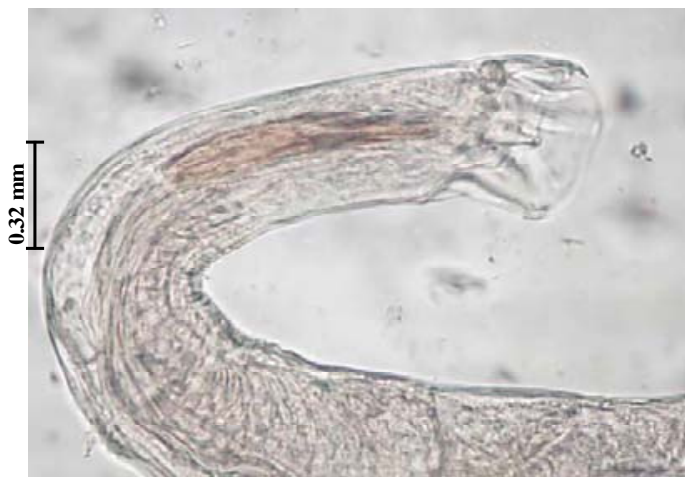

B

Fig. 1: Oswaldocruzia filiformis A - Anterior end B - Posterior end of male

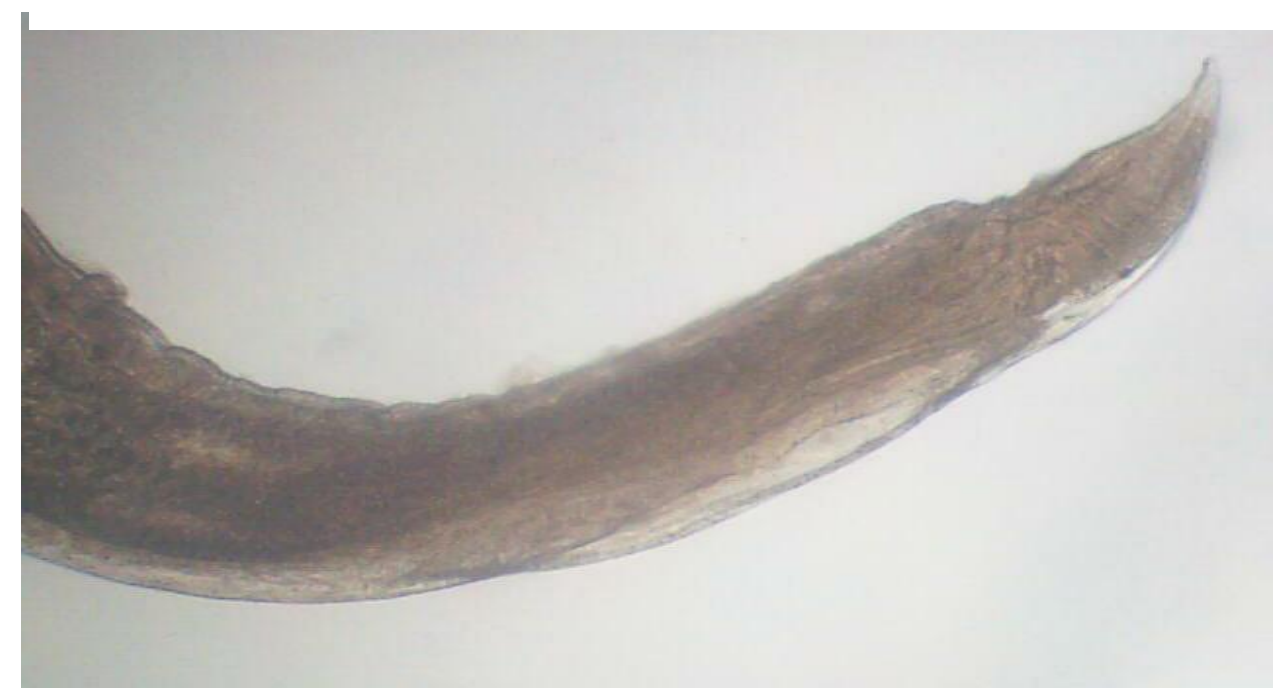

Fig. 2: Cosmocerca commutate Posterior end of the female

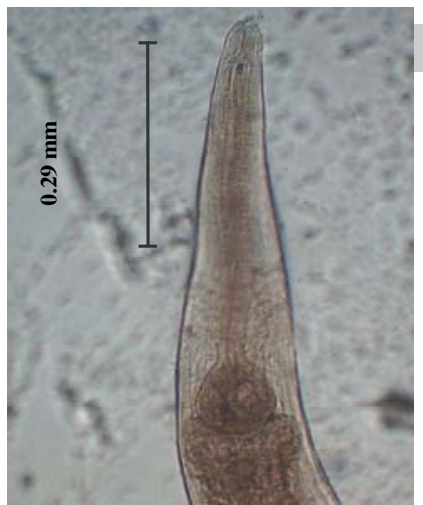

A

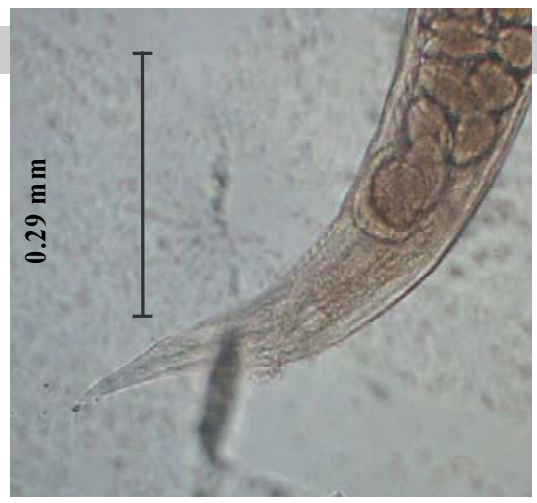

B

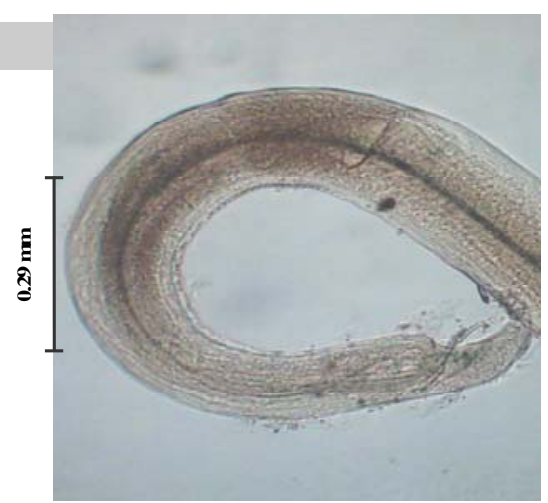

C

Fig. 3: Cosmocercoides variabilis A - Anterior end. B - Posterior end of the female C- Posterior end of the male 


\section{ARABIC SUMMARY}

طفيليات العلجوم الاخضر Bufo viridis Laurenti, 1768 في مدينة بغداد وسط العراق

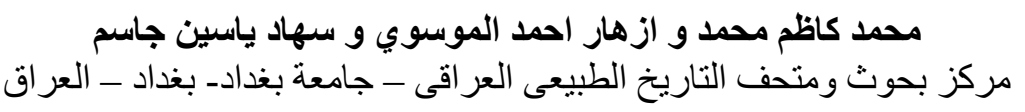

خلال فحص لعينة صغيرة من العلجوم الاخضر و التي تم جمعها من مدينة بغداد ، وسط العر اق تم التم الحصول

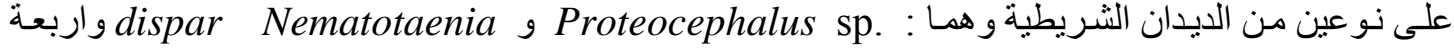

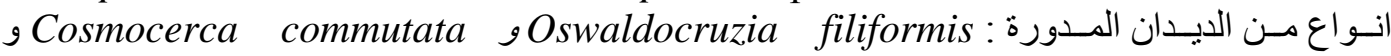
Rhabdias bufonis, Cosmocercoides variabilis 